\title{
A Review of Current Keloid Management: Mainstay Monotherapies and Emerging Approaches
}

Emily E. Limmer · Donald A. Glass II

Received: May 15, 2020 / Published online: July 23, 2020

(C) The Author(s) 2020

\section{ABSTRACT}

Commonly affecting those with skin of color, keloids are an aberrant wound response that leads to wound tissue expanding above and beyond the original cutaneous injury. Keloids are notoriously and particularly difficult to treat because of their tendency to recur after excision. The current standard of care is intralesional steroid (triamcinolone acetonide). However, because no therapy has yet proven to be fully curative, keloid treatments have expanded to include a number of options, from injections to multimodal approaches. This review details current treatment of keloids with injections (bleomycin, verapamil, hyaluronic acid and hyaluronidase, botulinum toxin, and collagenase), cryotherapy, laser, radiofrequency ablation, radiation, extracorporeal shockwave therapy, pentoxifylline, and dupilumab.

Keywords: $\mathrm{CO}_{2}$ laser; Cryotherapy; Intralesional injection; Keloid; Multimodal approach;

Digital Features To view digital features for this article go to https://doi.org/10.6084/m9.figshare.12624782.

E. E. Limmer · D. A. Glass II ( $₫)$

Department of Dermatology, UT Southwestern

Medical Center, Dallas, TX, USA

e-mail: Donald.Glass@UTSouthwestern.edu
Pulse dye laser; Radiation; Radiofrequency ablation; Wound healing

\section{Key Summary Points}

Keloids are a pathologic response to cutaneous injury in which wound tissue grows beyond the inciting insult.

Because keloids are prone to postexcisional recurrence, medical management plays an important role in keloid treatment.

While the standard of care for keloids is intralesional steroid (triamcinolone acetonide), new and innovative therapeutic options offer the possibility to improve and tailor management to patient preferences and qualities.

Expanding from triamcinolone acetonide alone, injection options now include bleomycin, verapamil, hyaluronic acid and hyaluronidase, botulinum toxin, and collagenase.

Additional treatment options discussed include cryotherapy, laser, radiofrequency ablation, radiation, extracorporeal shockwave therapy, pentoxifylline, and dupilumab. 


\section{INTRODUCTION}

Keloids are a pathologic response to cutaneous injury in which wound tissue grows above and beyond the inciting insult. These lesions disproportionally affect patients with skin of color, especially of African, Asian, and Hispanic backgrounds [1]. Keloids can be cosmetically disfiguring as well as symptomatically distressing, commonly causing pruritus, pain, and decreased quality of life [2].

The standard of care for keloids differs geographically; steroid-impregnated tape is the first-line treatment modality in Japan, while steroid (triamcinolone acetonide) injections are the treatment of choice in the USA $[1,3]$. Other common treatments include silicone sheets, compression, intralesional administration of 5-fluorouracil, and excision. Anecdotal accounts report some improvement with topical tea tree oil and over-the-counter antihistamines. However, because no treatment has been found to be fully effective at inducing regression of keloid tissue or at preventing postoperative recurrence, much work is being done to elucidate the underlying pathology of these lesions and to devise better treatments. The use of new, innovative therapeutic options, including combinations of previously described treatments, offers the possibility of lesion regression and/or symptomatic improvement. We have gathered data assessing current therapeutic options for keloids, including new treatment options and multimodal approaches. Treatments discussed in this review include injections (bleomycin, verapamil, hyaluronic acid and hyaluronidase, botulinum toxin, and collagenase), cryotherapy, laser, radiofrequency ablation, radiation, extracorporeal shockwave therapy, pentoxifylline, and dupilumab (Table 1).

This article is based on previously conducted studies and does not contain any studies with human participants or animals performed by any of the authors.

\section{INJECTIONS}

\section{Bleomycin}

The chemotherapeutic drug bleomycin has been used in the treatment of keloids and hypertrophic scars for decades owing to its antitumoral properties and potential reduction in collagen generation [4]. Initial studies of both bleomycin injection and topical application with penetration enhanced via multiple needle punctures showed therapeutic benefit $[5,6]$. Use of a combination bleomycin and triamcinolone injection was found to be effective in a study of 35 keloids and two hypertrophic scars in 10 white patients. Four milligrams of triamcinolone plus $0.375 \mathrm{IU}$ bleomycin per $\mathrm{cm}^{2}$ led to softening of $97.3 \%$ of lesions and flattening of $64.9 \%$ of lesions after one and two sessions, respectively. Dermal atrophy was originally noted in several lesions but was only present in one lesion at 24 months. Adverse effects of this method included ulceration. While neither hyper- nor hypopigmentation was noted, these participants had Fitzpatrick skin types II-IV [7]. In another study, no statistical difference was found between outcomes of intralesionally injected bleomycin versus triamcinolone; however, this study included patients of slightly darker skin tone (Fitzpatrick III-V) and hyperpigmentation was seen in $71.4 \%$ of participants [8]. Pain is often experienced with bleomycin use $[7,8]$. A study of 35 lesions treated with intralesional administration of bleomycin and electroporation showed a decrease in height and volume in all lesions [9]. In sum, while bleomycin has shown efficacy in treatment of keloids, caution should be used in patients with skin of color because of possible pigmentary changes [8].

\section{Verapamil}

The calcium channel blocker verapamil was proposed initially for keloid treatment owing to its potential to block fibrosis in in vitro studies [10]. However, this treatment has seen quite mixed results. A single-arm study using intralesional administration of verapamil intra- and 
Table 1 Details of referenced studies by treatment

\begin{tabular}{|c|c|c|c|c|}
\hline Treatment method & Design & $\begin{array}{l}\text { No. lesions } \\
\text { \{no. patients\} }\end{array}$ & Primary results & $\begin{array}{l}\text { Author (year) } \\
\text { [Reference] }\end{array}$ \\
\hline \multicolumn{5}{|l|}{ Bleomycin } \\
\hline $\begin{array}{l}\text { Needle puncture } \\
\text { application }\end{array}$ & $\begin{array}{l}\text { Treatment comparison to } \\
\text { baseline keloid and } \\
\text { hypertrophic scar (HTS) }\end{array}$ & $\begin{array}{c}13 \text { (7 keloid, } 6 \\
\text { HTS) }\{13\}\end{array}$ & $\begin{array}{l}\text { 13/13 flattened, } 2 / 13 \\
\text { recurrences }\end{array}$ & $\begin{array}{r}\text { Espana et al. } \\
\text { (2001) [5] }\end{array}$ \\
\hline Intralesional injection & Treatment trial & $\begin{array}{l}40 \text { (35 keloids, } \\
5 \text { HTS) } \\
\text { \{unreported\} }\end{array}$ & $\begin{array}{l}\text { Efficacy in } 100 \% \text { of lesions, } \\
5 / 36 \text { failed to achieve } \\
\text { good results }\end{array}$ & $\begin{array}{l}\text { Bodokh and } \\
\text { Brun (1996) } \\
{[6]}\end{array}$ \\
\hline Intralesional injection & $\begin{array}{l}\text { Combination with } \\
\text { triamcinolone }\end{array}$ & $\begin{array}{l}43 \text { (41 keloid, } \\
2 \text { HTS) }\{10\}\end{array}$ & $\begin{array}{l}\text { 36/38 softened with } 1 \\
\text { treatment, } 24 / 38 \\
\text { flattened with } 2 \\
\text { treatments }\end{array}$ & $\begin{array}{l}\text { Camacho- } \\
\text { Martinez } \\
\text { et al. (2013) } \\
\text { [7] }\end{array}$ \\
\hline Intralesional injection & $\begin{array}{l}\text { Comparison to } \\
\text { triamcinolone }\end{array}$ & $\begin{array}{l}26 \text { (19 keloid, } \\
7 \text { HTS) }\{26\}\end{array}$ & No difference in outcomes & $\begin{array}{l}\text { Payapvipapong } \\
\text { et al. (2015) } \\
{[8]}\end{array}$ \\
\hline $\begin{array}{l}\text { Intravenous injection } \\
\text { with electroporation }\end{array}$ & Treatment trial & $\begin{array}{l}35 \text { (keloid and } \\
\text { HTS) }\{20\}\end{array}$ & $\begin{array}{l}100 \% \text { response rate, average } \\
87 \% \text { volume reduction }\end{array}$ & $\begin{array}{l}\text { Manca et al. } \\
\text { (2013) [9] }\end{array}$ \\
\hline \multicolumn{5}{|l|}{ Verapamil } \\
\hline Intralesional injection & $\begin{array}{l}\text { Comparison to } \\
\text { triamcinolone post excision }\end{array}$ & $14\{14\}$ & $\begin{array}{l}\text { Verapamil not as effective } \\
\text { for prevention of } \\
\text { recurrence }(p=0.01)\end{array}$ & $\begin{array}{l}\text { Danielsen et al. } \\
\text { (2016) [10] }\end{array}$ \\
\hline Intralesional injection & Treatment trial & $19\{16\}$ & $\begin{array}{l}71.4 \% \text { response rate, } 4 / 14 \\
\text { recurrences }\end{array}$ & $\begin{array}{l}\text { El-Kamel et al. } \\
\text { (2016) [11] }\end{array}$ \\
\hline Intralesional injection & $\begin{array}{l}\text { Comparison to } \\
\text { triamcinolone, } \\
\text { triamcinolone with } \\
\text { hyaluronidase, intralesional } \\
\text { RF, intralesional RF with } \\
\text { triamcinolone }\end{array}$ & $100\{100\}$ & $\begin{array}{l}0 \% \text { clearance rate with } \\
\text { intralesional } \\
\text { administration of } \\
\text { verapamil }\end{array}$ & $\begin{array}{l}\text { Aggarwal et al. } \\
(2018)[12]\end{array}$ \\
\hline Intralesional injection & $\begin{array}{l}\text { Comparison to } \\
\text { triamcinolone }\end{array}$ & $\begin{array}{l}100 \text { (keloid } \\
\text { and HTS) } \\
\{50\}\end{array}$ & $\begin{array}{l}\text { No clinical improvement } \\
\text { with verapamil }\end{array}$ & $\begin{array}{l}\text { Abedini et al. } \\
\text { (2018) [13] }\end{array}$ \\
\hline Intralesional injection & $\begin{array}{l}\text { Comparison to } \\
\text { triamcinolone }\end{array}$ & $\begin{array}{c}48 \text { (keloid and } \\
\text { HTS) }\{40\}\end{array}$ & $\begin{array}{l}\text { Similar effectiveness in both } \\
\text { groups }\end{array}$ & $\begin{array}{l}\text { Ahuja and } \\
\text { Chatterjee } \\
(2014)[14]\end{array}$ \\
\hline Intralesional injection & $\begin{array}{l}\text { Comparison to } \\
\text { triamcinolone }\end{array}$ & $\begin{array}{l}54 \text { (keloid and } \\
\text { HTS) }\{54\}\end{array}$ & $\begin{array}{l}\text { Similar effectiveness in both } \\
\text { groups }\end{array}$ & $\begin{array}{l}\text { Margaret et al. } \\
\quad(2008)[15]\end{array}$ \\
\hline
\end{tabular}


Table 1 continued

\begin{tabular}{|c|c|c|c|c|}
\hline Treatment method & Design & $\begin{array}{l}\text { No. lesions } \\
\text { \{no. patients\} }\end{array}$ & Primary results & $\begin{array}{l}\text { Author (year) } \\
\text { [Reference] }\end{array}$ \\
\hline Intralesional injection & $\begin{array}{l}\text { Comparison to control post } \\
\text { excision }\end{array}$ & $44\{44\}$ & $\begin{array}{l}54 \% \text { complete clearance } \\
\text { with adjunct verapamil } \\
\text { versus } 0 \% \text { control } \\
\text { clearance }\end{array}$ & $\begin{array}{l}\text { D'Andrea et al. } \\
\text { (2002) [16] }\end{array}$ \\
\hline \multicolumn{5}{|l|}{ Hyaluronic acid } \\
\hline Intralesional injection & $\begin{array}{l}\text { Case report using } \\
\text { combination hyaluronic } \\
\text { acid and triamcinolone }\end{array}$ & $1\{1\}$ & $\begin{array}{l}\text { Complete keloid } \\
\text { reabsorption }\end{array}$ & $\begin{array}{l}\text { Di Stadio } \\
\quad(2016)[18]\end{array}$ \\
\hline Intralesional injection & $\begin{array}{l}\text { Comparison to } \\
\text { triamcinolone, intralesional } \\
\text { administration of } \\
\text { verapamil, intralesional RF, } \\
\text { intralesional RF with } \\
\text { triamcinolone }\end{array}$ & $100\{100\}$ & $\begin{array}{l}68.75 \% \text { clearance rate with } \\
\text { intralesional } \\
\text { administration of } \\
\text { hyaluronic acid }\end{array}$ & $\begin{array}{l}\text { Aggarwal et al. } \\
(2018)[12]\end{array}$ \\
\hline \multicolumn{5}{|l|}{ Botulinum toxin } \\
\hline Intralesional injection & Treatment trial & $\begin{array}{l}1-3 \text { per } \\
\text { patient, }\{12\}\end{array}$ & $\begin{array}{l}\text { 12/12 reduced size, 12/12 } \\
\text { flattening, } 0 / 12 \\
\text { recurrence at } 1 \text {-year } \\
\text { follow-up }\end{array}$ & $\begin{array}{l}\text { Zhibo and } \\
\text { Miaobo } \\
(2009)[20]\end{array}$ \\
\hline \multirow[t]{2}{*}{ Intralesional injection } & Treatment trial & $4\{4\}$ & No clinical improvement & $\begin{array}{l}\text { Gauglitz et al. } \\
(2012)[21]\end{array}$ \\
\hline & $\begin{array}{l}\text { Treatment trial, } 8 / 12 \text { with } \\
\text { triamcinolone adjunctive } \\
\text { therapy }\end{array}$ & $12\{12\}$ & $\begin{array}{l}11 \text { months average to } \\
\text { flatten, } 2 / 12 \text { recurrences }\end{array}$ & $\begin{array}{l}\text { Robinson et al. } \\
\text { (2013) [22] }\end{array}$ \\
\hline Intralesional injection & $\begin{array}{l}\text { Comparison to } \\
\text { triamcinolone }\end{array}$ & $24\{24\}$ & $\begin{array}{l}\text { Similar effectiveness in both } \\
\text { groups }\end{array}$ & $\begin{array}{l}\text { Shaarawy et al. } \\
\text { (2015) [23] }\end{array}$ \\
\hline Intralesional injection & $\begin{array}{l}\text { Comparison to } \\
\text { triamcinolone, } \\
\text { combination with } \\
\text { triamcinolone }\end{array}$ & $66\{23\}$ & $\begin{array}{l}\text { Similar effectiveness in both } \\
\text { groups, increased } \\
\text { symptomatic } \\
\text { improvement }\end{array}$ & $\begin{array}{l}\text { Rasaii et al. } \\
\text { (2019) [24] }\end{array}$ \\
\hline Intralesional injection & $\begin{array}{l}\text { Comparison to } \\
\text { triamcinolone }\end{array}$ & $50\{25\}$ & $\begin{array}{l}\text { Superior outcome } \\
\text { longitudinally with } \\
\text { triamcinolone }\end{array}$ & $\begin{array}{l}\text { Pruksapong } \\
\text { et al. }(2017) \\
{[25]}\end{array}$ \\
\hline Intralesional injection & $\begin{array}{l}\text { Systemic review and meta- } \\
\text { analysis compared to } \\
\text { corticosteroid, keloid and } \\
\text { HTS }\end{array}$ & $\begin{array}{l}\text { Unreported } \\
\{639\}\end{array}$ & $\begin{array}{l}\text { Greater efficacy with } \\
\text { botulinum toxin }\end{array}$ & $\begin{array}{l}\text { Bi et al. (2019) } \\
\quad[26]\end{array}$ \\
\hline
\end{tabular}


Table 1 continued

\begin{tabular}{|c|c|c|c|c|}
\hline Treatment method & Design & $\begin{array}{l}\text { No. lesions } \\
\text { \{no. patients\} }\end{array}$ & Primary results & $\begin{array}{l}\text { Author (year) } \\
\text { [Reference] }\end{array}$ \\
\hline \multicolumn{5}{|l|}{ Collagenase } \\
\hline Intralesional injection & $\begin{array}{l}\text { Combination with } \\
\text { triamcinolone }\end{array}$ & $\begin{array}{c}5 \text { (3 keloid, } 2 \\
\text { HTS) }\{5\}\end{array}$ & $\begin{array}{l}\text { Recurrence of all lesions } \\
\text { after initial reduction }\end{array}$ & $\begin{array}{l}\text { Kang et al. } \\
\text { (2006) [28] }\end{array}$ \\
\hline Intralesional injection & $\begin{array}{l}\text { Combination with } \\
\text { compression }\end{array}$ & $6\{6\}$ & $\begin{array}{l}\text { Average } 50 \% \text { reduction, } 2 / 3 \\
\text { recurrence at } 12 \text {-month } \\
\text { follow-up }\end{array}$ & $\begin{array}{l}\text { Bae-Harboe } \\
\text { et al. (2014) } \\
\text { [29] }\end{array}$ \\
\hline \multicolumn{5}{|l|}{ Cryotherapy } \\
\hline $\begin{array}{l}\text { Spray treatment, } \\
\text { intralesional treatment }\end{array}$ & $\begin{array}{l}\text { Comparison spray versus } \\
\text { intralesional methods }\end{array}$ & $50\{50\}$ & $\begin{array}{l}\text { Greater improvement with } \\
\text { intralesional therapy }\end{array}$ & $\begin{array}{l}\text { Mourad et al. } \\
(2016)[30]\end{array}$ \\
\hline Spray treatment & $\begin{array}{l}\text { Treatment trial, post } \\
\text { keloidectomy }\end{array}$ & $97\{66\}$ & $\begin{array}{l}71 \% \text { of lesions showed } \\
\text { major flattening at } \\
24 \text { months follow-up }\end{array}$ & $\begin{array}{l}\text { Litrowski et al. } \\
\text { (2014) [31] }\end{array}$ \\
\hline Intralesional treatment & Treatment trial & $29\{27\}$ & $\begin{array}{l}\text { Average } 63 \% \text { reduction, } \\
24 \% \text { recurrence }\end{array}$ & $\begin{array}{l}\text { van Leeuwen } \\
\text { et al. (2015) } \\
\text { [32] }\end{array}$ \\
\hline Spray treatment & Treatment trial & $10\{6\}$ & $\begin{array}{l}\text { Limited short-term and no } \\
\text { long-term efficacy }\end{array}$ & $\begin{array}{l}\text { Park et al. } \\
\quad(2017)[33]\end{array}$ \\
\hline Intraoperative treatment & $\begin{array}{l}\text { Combination with excision } \\
\text { and platelet-rich plasma }\end{array}$ & $50\{50\}$ & $\begin{array}{l}\text { Average } 84 \% \text { improvement, } \\
\text { less than } 30 \% \\
\text { improvement in } 26 \% \text { of } \\
\text { lesions }\end{array}$ & $\begin{array}{l}\text { Azzam and } \\
\text { Omar (2018) } \\
{[34]}\end{array}$ \\
\hline Probe treatment & $\begin{array}{l}\text { Treatment trial (before } \\
\text { intralesional administration } \\
\text { of triamcinolone) }\end{array}$ & $35\{30\}$ & $\begin{array}{l}\text { Significantly less pain } \\
(p<0.1) \text { compared to } \\
\text { control }\end{array}$ & $\begin{array}{l}\text { Wang et al. } \\
\qquad(2017)[35]\end{array}$ \\
\hline \multicolumn{5}{|l|}{ Laser } \\
\hline $\begin{array}{l}585 \mathrm{~nm} \text { pulse dye laser } \\
(\mathrm{PDL})\end{array}$ & Case report & $1\{1\}$ & $\begin{array}{l}\text { Recurrence of previously } \\
\text { flattened lesion }\end{array}$ & $\begin{array}{l}\text { Shih et al. } \\
\text { (2008) [37] }\end{array}$ \\
\hline $595 \mathrm{~nm} \mathrm{PDL}$ & Case series & $3\{3\}$ & Recurrence in $0 / 3$ lesions & $\begin{array}{l}\text { Eke et al. } \\
\text { (2013) [38] }\end{array}$ \\
\hline $595 \mathrm{~nm}$ PDL & Treatment trial & $52\{26\}$ & $\begin{array}{l}\text { Significant decrease in VSS } \\
\quad \text { score }(20.85 \pm 12.33 \%)\end{array}$ & $\begin{array}{l}\text { Yang et al. } \\
\text { (2012) [39] }\end{array}$ \\
\hline $585 \mathrm{~nm}$ PDL & Treatment trial & $\begin{array}{l}59 \text { (HTS and } \\
\text { keloids) }\{59\}\end{array}$ & $\begin{array}{c}\text { 44/59 patients achieved } \\
\text { moderate to excellent } \\
\text { clearance, } 3 / 59 \text { saw } \\
\text { minimal improvement }\end{array}$ & $\begin{array}{l}\text { Cannarozzo } \\
\text { et al. }(2015) \\
{[40]}\end{array}$ \\
\hline
\end{tabular}


Table 1 continued

\begin{tabular}{|c|c|c|c|c|}
\hline Treatment method & Design & $\begin{array}{l}\text { No. lesions } \\
\text { \{no. patients\} }\end{array}$ & Primary results & $\begin{array}{l}\text { Author (year) } \\
\text { [Reference] }\end{array}$ \\
\hline 595 nm PDL & $\begin{array}{l}\text { In vitro study of treated } \\
\text { fibroblasts }\end{array}$ & $20\{20\}$ & $\begin{array}{l}\text { Significantly fewer } \\
\text { fibroblasts in proliferative } \\
\text { phases of the cell cycle } \\
\text { after treatment }\end{array}$ & $\begin{array}{l}\text { Zhibo and } \\
\text { Miaobo } \\
(2010)[41]\end{array}$ \\
\hline Fractional $\mathrm{CO}_{2}$ laser & Treatment trial & $\begin{array}{l}19 \text { (12 keloid, } \\
7 \text { HTS) }\{19\}\end{array}$ & $\begin{array}{l}\text { Significantly decreased VSS } \\
\text { in treatment group, low } \\
\text { patient satisfaction }\end{array}$ & $\begin{array}{l}\text { Azzam et al. } \\
\text { (2016) [42] }\end{array}$ \\
\hline Fractional $\mathrm{CO}_{2}$ laser & $\begin{array}{l}\text { Case report, combination } \\
\text { with laser-assisted drug } \\
\text { delivery of topical } \\
\text { triamcinolone }\end{array}$ & $1\{1\}$ & $\begin{array}{l}\text { Scar thinning and visual } \\
\text { improvement noted }\end{array}$ & $\begin{array}{l}\text { Kraeva et al. } \\
\text { (2017) [43] }\end{array}$ \\
\hline $\begin{array}{r}300 \mu \mathrm{s} 1064 \mathrm{~nm} \\
\text { Nd:YAG laser }\end{array}$ & $\begin{array}{l}\text { Comparison to } \\
\text { triamcinolone and } \\
\text { combination }\end{array}$ & $44\{44\}$ & $\begin{array}{l}\text { Greater efficacy in the laser } \\
\text { only and combination } \\
\text { therapy group }\end{array}$ & $\begin{array}{l}\text { Rossi et al. } \\
\qquad(2013)[44]\end{array}$ \\
\hline $\begin{array}{l}595 \text { nm PDL, } 1064 \mathrm{~nm} \\
\text { Nd:YAG }\end{array}$ & $\begin{array}{l}\text { Comparison of laser } \\
\text { treatments }\end{array}$ & $\begin{array}{l}20 \text { (9 keloid, } \\
\quad 11 \text { HTS) } \\
\{20\}\end{array}$ & $\begin{array}{l}\text { Similar effectiveness in both } \\
\text { groups }\end{array}$ & $\begin{array}{l}\text { Al-Mohamady } \\
\text { et al. (2016) } \\
{[45]}\end{array}$ \\
\hline $585 \mathrm{~nm}$ PDL & $\begin{array}{l}\text { Case report, combination } \\
\text { with } \mathrm{CO}_{2} \text { laser and } \\
\text { triamcinolone }\end{array}$ & $\begin{array}{l}\text { Unreported } \\
\quad\{1\}\end{array}$ & $\begin{array}{l}\text { Symptomatic improvement } \\
\text { and clinical regression }\end{array}$ & $\begin{array}{l}\text { Martin and } \\
\text { Collawn } \\
(2013)[46]\end{array}$ \\
\hline \multicolumn{5}{|c|}{ Radiofrequency (RF) ablation } \\
\hline $6 \mathrm{MHz}$ & Treatment trial & $\begin{array}{c}10 \text { (6 keloid, } 4 \\
\text { HTS) }\{10\}\end{array}$ & $\begin{array}{l}\text { No significant } \\
\text { improvement seen }\end{array}$ & $\begin{array}{l}\text { Meshkinpour } \\
\text { et al. (2005) } \\
{[47]}\end{array}$ \\
\hline $12 \mathrm{~W}$ electrode & $\begin{array}{l}\text { Treatment trial and } \\
\text { comparison with } \\
\text { combination triamcinolone }\end{array}$ & $19\{14\}$ & $\begin{array}{l}\text { Improvement in } 6 / 7 \text { lesions } \\
\text { with combination } \\
\text { therapy, improvement in } \\
4 / 7 \text { monotherapy }\end{array}$ & $\begin{array}{l}\text { Fruth et al. } \\
\qquad(2011)[48]\end{array}$ \\
\hline $10 \mathrm{~W}$ electrode & Treatment trial & $13\{11\}$ & $\begin{array}{l}\text { 10/11 had significant } \\
\text { improvement after } 1 \\
\text { treatment }\end{array}$ & $\begin{array}{r}\text { Klockars et al. } \\
(2013) \text { [49] }\end{array}$ \\
\hline $4 \mathrm{MHz}$ & $\begin{array}{l}\text { Combination with } \\
\text { triamcinolone }\end{array}$ & $18\{18\}$ & $\begin{array}{l}\text { Average } 95.4 \% \text { decreased } \\
\text { volume }\end{array}$ & $\begin{array}{l}\text { Weshay et al. } \\
\text { (2015) [50] }\end{array}$ \\
\hline
\end{tabular}


Table 1 continued

\begin{tabular}{|c|c|c|c|c|}
\hline Treatment method & Design & $\begin{array}{l}\text { No. lesions } \\
\text { \{no. patients\} }\end{array}$ & Primary results & $\begin{array}{l}\text { Author (year) } \\
\text { [Reference] }\end{array}$ \\
\hline Intralesional RF & $\begin{array}{l}\text { Comparison of intralesional } \\
\text { RF and intralesional RF } \\
\text { with triamcinolone versus } \\
\text { triamcinolone, } \\
\text { triamcinolone with } \\
\text { hyaluronidase, and } \\
\text { intralesional administration } \\
\text { of verapamil }\end{array}$ & $100\{100\}$ & $\begin{array}{l}\text { 11.76\% clearance with } \\
\text { intralesional RF alone, } \\
75 \% \text { clearance } \\
\text { combination RF and } \\
\text { triamcinolone }\end{array}$ & $\begin{array}{l}\text { Aggarwal et al. } \\
(2018)[12]\end{array}$ \\
\hline \multicolumn{5}{|l|}{ Radiation } \\
\hline $\begin{array}{l}\text { Post-excision electron } \\
\text { beam }\end{array}$ & $\begin{array}{l}\text { Comparison to previous } \\
\text { literature on kilovoltage } \\
\text { X-ray }\end{array}$ & $50\{36\}$ & $\begin{array}{l}16 \% \text { recurrence rate, } 83 \% \\
\text { satisfaction, greater results } \\
\text { with electron beam }\end{array}$ & $\begin{array}{r}\text { Maarouf et al. } \\
(2002)[51]\end{array}$ \\
\hline $\begin{array}{l}\text { Electron beam, }{ }^{60} \mathrm{Co}, \mathrm{kV} \\
\text { X-ray, }{ }^{90} \mathrm{Sr}\end{array}$ & Meta-analysis & $2515\{2515\}$ & $\begin{array}{l}{ }^{60} \text { Co and electron beam } \\
\text { were significantly more } \\
\text { effective }(p=0.0014)\end{array}$ & $\begin{array}{l}\text { Flickinger } \\
\qquad(2011)[52]\end{array}$ \\
\hline $\begin{array}{l}\text { Post-excision electron } \\
\text { beam }\end{array}$ & Treatment trial & $834\{568\}$ & $\begin{array}{l}9.59 \% \text { recurrence rate, most } \\
\text { effective results with } \\
\text { treatment }<24 \mathrm{~h} \text { after } \\
\text { excision }\end{array}$ & $\begin{array}{l}\text { Shen et al. } \\
\qquad(2015)[53]\end{array}$ \\
\hline Superficial kV X-ray & $\begin{array}{l}\text { Treatment trial of parallel } \\
\text { pair method for auricular } \\
\text { keloids }\end{array}$ & $18\{16\}$ & $\begin{array}{l}\text { Treatment satisfaction } 4.7 / \\
5\end{array}$ & $\begin{array}{l}\text { Eaton et al. } \\
\qquad(2012)[54]\end{array}$ \\
\hline $\begin{array}{l}\text { High-dose-rate } \\
\text { brachytherapy }\end{array}$ & Treatment trial & $32\{24\}$ & $\begin{array}{l}6 \% \text { recurrence, } 100 \% \\
\text { symptomatic reduction }\end{array}$ & $\begin{array}{l}\text { Jiang et al. } \\
\text { (2016) [55] }\end{array}$ \\
\hline Superficial photon & $\begin{array}{l}\text { Combination with excision } \\
\text { and platelet-rich plasma }\end{array}$ & $21\{20\}$ & $\begin{array}{l}0 \% \text { recurrence rate, } 2 / 21 \\
\text { with poor results (Kyoto } \\
\text { Scale) }\end{array}$ & $\begin{array}{l}\text { Jones et al. } \\
\qquad(2016)[56]\end{array}$ \\
\hline Photon & $\begin{array}{l}\text { Treatment trial, comparison } \\
\text { to previous literature } \\
\text { regarding electron beam } \\
\text { radiation }\end{array}$ & $15\{14\}$ & $\begin{array}{l}0 \% \text { recurrence at } 22.5- \\
\text { month follow-up, } \\
\text { comparable results with } \\
\text { both methods }\end{array}$ & $\begin{array}{l}\text { Yang et al. } \\
\text { (2019) [57] }\end{array}$ \\
\hline Electron beam & $\begin{array}{l}\text { Combination with excision, } \\
\text { comparison to excision } \\
\text { with 5-fluorouracil and } \\
\text { triamcinolone intralesional } \\
\text { injection }\end{array}$ & $60\{60\}$ & $\begin{array}{l}\text { Electron beam inferior to } \\
\text { injections at reducing } \\
\text { recurrence ( } 42.33 \% \text { versus } \\
73.33 \% \text {, respectively) }\end{array}$ & $\begin{array}{l}\text { Khalid et al. } \\
\qquad(2018)[58]\end{array}$ \\
\hline
\end{tabular}


Table 1 continued

Treatment method

$$
\text { Design }
$$

No. lesions

Primary results

\{no. patients\}

Author (year)

[Reference]

\section{Extracorporeal shockwave therapy}

Handheld probe device
Comparison to intralesional administration of
triamcinolone

$39\{39\}$

Similar effectiveness in both Wang et al. groups

(2018) [60]

\section{Pentoxifylline}

$400 \mathrm{mg}$, BID or TID Case series

Unreported

Symptomatic relief (pain,

Wong et al. pruritus) in all patients

$400 \mathrm{mg}$, TID, 6 months
Perioperative treatment trial $67\{45\}$ in combination with intralesional administration of triamcinolone

Recurrence significantly

Tan et al. reduced in high risk patients $(10.5 \%$ versus $66.6 \%)$

\section{Dupilumab}

$300 \mathrm{mg}$ every 2 weeks Case report $\quad 2\{1\}$
Substantial keloid regression without
complete clearance

(2019) [63]

\section{Combination therapies}

$\mathrm{CO}_{2}$ laser, compression, silicone sheets, and cyanoacrylate glue

Fractional erbium-glass laser, $\mathrm{CO}_{2}$ laser, cryotherapy, and intralesional administration of triamcinolone

RF ablation and electron beam radiation

Combination treatment trial $7\{7\}$

Good outcomes, 100\%

Tenna et al.

$$
\text { patient satisfaction }
$$

Combination treatment trial Unreported

$5 \%$ recurrence rate, highly

Lee et al. efficacious compared to previous literature

detailing the

monotherapies

Combination treatment trial Unreported

Good or fair outcomes

Zhang et al.

(72.7\% and $27.3 \%$,

(2019) [67]

respectively), $73.3 \%$

patient satisfaction

Similar effectiveness in both Behera et al. groups (2016) [68]
$\mathrm{CO}_{2}$ laser versus cryotherapy

\section{Comparisons}

cryotherapy

Randomized controlled trial, $101\{60\}$ both interventions followed by intralesional administration of triamcinolone 
Table 1 continued

\begin{tabular}{|c|c|c|c|c|}
\hline Treatment method & Design & $\begin{array}{l}\text { No. lesions } \\
\text { \{no. patients\} }\end{array}$ & Primary results & $\begin{array}{l}\text { Author (year) } \\
\text { [Reference] }\end{array}$ \\
\hline $\begin{array}{c}\mathrm{CO}_{2} \text { laser with topical } \\
\text { verapamil or topical } \\
\text { 5-fluorouracil versus } \\
\mathrm{CO}_{2} \text { monotherapy }\end{array}$ & Randomized trial & $\begin{array}{l}\text { Unreported } \\
\qquad \text { (keloid and } \\
\text { HTS) }\{30\}\end{array}$ & $\begin{array}{l}\text { Greater efficacy with } \\
\text { combined therapy than } \\
\mathrm{CO}_{2} \text { laser alone }\end{array}$ & $\begin{array}{l}\text { Sabry et al. } \\
\qquad(2019)[69]\end{array}$ \\
\hline $\begin{array}{l}\text { Intralesional cryotherapy } \\
\text { versus excision and } \\
\text { triamcinolone versus } \\
\text { excision and } \\
\text { brachytherapy }\end{array}$ & Randomized trial & $25\{25\}$ & $\begin{array}{l}\text { Intralesional cryotherapy } \\
\text { significantly less } \\
\text { efficacious than } \\
\text { brachytherapy to treat } \\
\text { previously unresponsive } \\
\text { keloids }\end{array}$ & $\begin{array}{l}\text { Bijlard et al. } \\
(2018)[70]\end{array}$ \\
\hline
\end{tabular}

postoperatively (every 2 weeks for 1 month, subsequently once per month for three additional months) concluded that verapamil was an acceptable treatment, with a recurrence rate of $28.6 \%$ [11]. However, compared to the standard of care (triamcinolone), another study found that postoperative sites injected monthly with $2.5 \mathrm{mg} / \mathrm{ml}$ verapamil showed higher recurrence rates than those injected with $10 \mathrm{mg} / \mathrm{ml}$ triamcinolone (hazard ratio $=8.44$, $p=0.01$ ). The results of this trial are particularly significant because of its study design that featured intra-patient control; half of the scar was injected with verapamil and half with triamcinolone [10]. In a third study, intralesional injection of verapamil was again found to be inferior to triamcinolone with verapamil having a complete clearance rate of $0 \%(0 / 15)$ versus $75 \%$ for triamcinolone (12/16) [12]. An additional study similarly found no evidence of efficacy for intralesional administration of verapamil; it did not reduce height nor pigmentation, and showed a minimal reduction in pliability [13]. These newer results contrast with previous literature which found verapamil effective for both keloids and hypertrophic scars [14-16]. These conflicting results make future use of intralesional verapamil therapy in keloids quite unclear.

\section{Hyaluronic Acid and Hyaluronidase}

From prevention of tumor growth to improvement of osteoarthritis to use in contact lenses, hyaluronic acid is a versatile mucopolysaccharide that is used in medical practice. In the field of dermatology, it has been used to improve skin contour and volume via injection fillers [17]. A recent case report using a combination of cortisone and hyaluronic acid over two sessions led to full clearance of the keloid with no recurrence seen at 12 months in a lesion previously refractory to cortisone injections alone [18]. Counterintuitively, an intralesional combination of triamcinolone $40 \mathrm{mg} / \mathrm{ml}$ mixed $1: 1$ with hyaluronidase $1500 \mathrm{IU} / \mathrm{ml}$ was also found to reduce keloid height to at most $1 \mathrm{~mm}$ in $11 / 16$ lesions $(68.75 \%$, similar to $12 / 16$ lesions (75\%) with $40 \mathrm{mg} / \mathrm{ml}$ intralesional administration of triamcinolone alone). The authors state that this could be due to a synergistic effect of triamcinolone with hyaluronidase, as this mixture with a final triamcinolone concentration of $20 \mathrm{mg} / \mathrm{ml}$ was as efficacious as $40 \mathrm{mg} / \mathrm{ml}$ alone [12]. While the case report cites potential anti- 
inflammatory properties of hyaluronic acid shown previously in animal studies of tendons, this does not fully explain why an implied reduction in hyaluronic acid with hyaluronidase would lead to similar results [19]. As both of these studies used combination therapy rather than hyaluronic acid or hyaluronidase alone, it may be that hyaluronidase or hyaluronic acid potentiated cortisone or triamcinolone, respectively, and did not lead to clearance of keloidal lesions of their own accord. Nevertheless, further study is warranted to illuminate the pathophysiological basis behind these conflicting results.

\section{Botulinum Toxin}

The initial trial of botulinum toxin for the treatment of keloids involved 12 patients and saw reduced size and increased flattening in all patients, with no recurrence at 1-year follow-up. Proposed mechanisms of action included both a reduction in scar tension as well as shifting cells to a more quiescent state [20]. While a subsequent study $(n=4)$ saw no clinical improvement in keloids with botulinum toxin therapy, further research has been largely supportive of this therapeutic response [21, 22]. Data has been mixed, however, as to how botulinum toxin compares to steroid injections. While studies such as those by Shaarawy et al. and Rasaii et al. found no difference between the two treatments, Pruksapong et al. found steroids to be superior, while a metanalysis performed by $\mathrm{Bi}$ et al. showed botulinum toxin as superior [23-26]. Factors such as decreased adverse effects and greater improvement in symptoms offer additional benefits of botulinum toxin in comparison to triamcinolone [23, 24]. Recent work using botulinum toxin in a mouse keloid model showed decreased Ki-67 (denoting decreased cell proliferation) as well as fewer and less haphazardly arranged collagen bundles, findings which were comparable to treatment of their mouse keloid model with steroid injections [27].

\section{Collagenase}

Collagenase injection currently has limited evidence. The initial evaluation yielded unsatisfactory results, as an initial reduction in keloid size in three patients (60\%) was followed by recurrence in all lesions. Common side effects included pain and ulceration; pyrexia was observed in one patient [28]. A more recent study of auricular keloids $(n=6)$ found collagenase injections in combination with compression earrings to result in an average 50\% size reduction in lesions; however, recurrence was a problem at 10-month and 1-year followup in two out of three lesions. The other three participants elected subsequent surgical treatment of their lesions, so this treatment may have use in shrinking lesions preoperatively. Compression and collagenase therapy may be especially helpful in combination, as both help to break down aberrant collagen known to be pathogenic in keloids [29]. Despite mixed results, the proposed mechanism of action of collagenase in the setting of keloids and their known connection with collagen production encourages additional research involving this therapy.

\section{CRYOTHERAPY}

Cryotherapy has quickly become a popular modality for discussion in keloid literature; when used to treat keloids, cryotherapy leads to both decreased inflammation and increased collagen organization [30]. In a retrospective study of 97 auricular lesions treated with immediate cryotherapy post keloidectomy, 71\% of keloids showed $80-100 \%$ flattening at 24 months follow-up. Although there was a $36 \%$ recurrence rate after one treatment, $68 \%$ of these recurrent lesions achieved flattening after a second treatment. Hypopigmentation was seen more in patients with darker skin; however, this did not reach significance, possibly as a result of a largely European population [31]. This is supported by results from a different study that found that both hypopigmentation and recurrence after intralesional cryotherapy were significantly more likely in patients with 
Fitzpatrick type V-VI than I-II [32]. Comparing intralesional to spray cryotherapy, the former seemed to be more effective, although good results were seen with both. Spray also required a larger number of sessions (2 weeks apart) to achieve similar results [30]. Results of a smaller study done by Park et al. using spray cryotherapy supported the need for sessions at 2-week intervals to maintain results. Additionally, they saw substandard results for several cases, particularly for thicker keloids, and thus concluded that spray treatment should not be performed as monotherapy [33]. Combination therapy of excision, handheld cryotherapy, and plateletrich plasma found an average Vancouver Scar Scale (VSS) improvement of $84 \%$, although $26 \%$ of lesions failed to flatten by more than $30 \%$. One hundred percent of patients experienced hyperpigmentation [34]. In sum, while cryotherapy is known to be painful, intralesional cryotherapy is efficacious, especially with newer lesions [30]. Table 2 lists the treatment specifications of the aforementioned cryosurgery studies. Cryotherapy also has a clear application in keloid treatment as anesthesia; a study using a cryotherapy probe before steroid injections showed a statistically significant reduction in reported pain [35].

\section{LASER}

Laser therapy continues to be of interest in the field of dermatology in general, and interest in its use with respect to keloids is no different.

\section{Pulse Dye Laser (PDL)}

PDL was one of the earliest laser interventions used to treat keloids. This type of laser destroys hemoglobin, making it useful in vascular keloids [36]. While an early case report actually found PDL $(585 \mathrm{~nm})$ to result in keloid recurrence after previous flattening, subsequent studies have shown efficacy in keloid treatment [37]. A case series $(n=3)$ found post-shave-excision PDL treatment $(595 \mathrm{~nm})$ of keloids to result in no recurrence of lesions $(0 / 3)$, and hypopigmentation was only seen in one patient [38]. A study of 26 patients with keloids who were treated with $595 \mathrm{~nm}$ PDL resulted in a significant decrease in VSS score, including improved pain and itch, pliability, and erythema [39]. Improvements were similarly seen in a study of 59 patients with keloids and hypertrophic scars (Fitzpatrick I-IV) treated with $585 \mathrm{~nm}$ PDL. Of 59 patients, 44 showed moderate to excellent results, with only $3 / 59$ patients resulting in minimal improvement. Of 59 patients, 55 were satisfied or very satisfied

Table 2 Cryotherapy specifications

\begin{tabular}{ccll}
\hline & Specifications & $\begin{array}{l}\text { Freeze-thaw } \\
\text { cycles }\end{array}$ & Additional information \\
\hline $\begin{array}{c}\text { Mourad et al. } \\
\text { [30] }\end{array}$ & $\begin{array}{c}\text { Spray or } \\
\text { intralesional }\end{array}$ & 1 & Pretreated with topical lidocaine, repeated every 2 weeks \\
$\begin{array}{c}\text { Litrowski } \\
\text { et al. [31] }\end{array}$ & $\begin{array}{c}\text { Post-excisional } \\
\text { spray }\end{array}$ & 1 & Stopped freezing when impedance meter reached $1000 \mathrm{k} \Omega$ \\
$\begin{array}{c}\text { van Leeuwen } \\
\text { et al. [32] }\end{array}$ & $\begin{array}{c}\text { Intralesional } \\
\begin{array}{c}\text { Park et al. } \\
\text { [33] }\end{array}\end{array}$ & 1 & Spray \\
$\begin{array}{c}\text { Azzam and } \\
\text { Omar [34] }\end{array}$ & $\begin{array}{c}\text { Intraoperative } \\
\text { treatment }\end{array}$ & 1 & Repeated every 2 weeks \\
\hline
\end{tabular}


with these results, although 7/59 exhibited some degree of hyperpigmentation [40]. Additional work to detail the mechanism of action of this efficacious treatment found that keloid fibroblasts treated with PDL had a statistically different cell cycle phase distribution than control fibroblasts, with the majority of treated fibroblasts being in G0 and G1 versus control fibroblasts being in proliferative phases [41]. With both a sound scientific basis and evidence of efficacy in trials, this treatment method could become a more common option for keloid treatment.

\section{Carbon Dioxide $\left(\mathrm{CO}_{2}\right)$ Laser}

More recent work has focused on the use of fractional carbon dioxide laser. An early study $\mathrm{CO}_{2}$ laser monotherapy (four sessions, 6 weeks apart) was shown to have mixed results in a study of both keloids and hypertrophic scars. While statistically significant reduction of VSS scores was seen (largely because of increased pliability), many patients were not satisfied with this therapy [42]. A case report found that treatment with fractionated $\mathrm{CO}_{2}$ laser and laserassisted drug delivery of topical triamcinolone caused scar thinning and visual improvement [43]. Such limited data makes these results difficult to generalize.

\section{Combinations and Comparisons}

Combination treatment using both triamcinolone and $300 \mu \mathrm{s} 1064 \mathrm{~nm}$ neodymium-doped yttrium aluminum garnet (Nd:YAG) laser (2000 pulses at $13-18 \mathrm{~J} / \mathrm{cm}^{2}$ ), an additional laser used for keloid treatment, reduced height and erythema to a greater degree than triamcinolone monotherapy. This study showed no adverse pigmentary changes, which is always a concern when treating these lesions on skin of color [44]. A study comparing Nd:YAG to PDL in 20 patients with keloids or hypertrophic scars found both therapies to be efficacious, with neither being statistically superior, although Nd:YAG was found to be more painful [45]. A case report using combination treatment including PDL, $\mathrm{CO}_{2}$ laser, and triamcinolone on a keloid that was previously unresponsive to triamcinolone alone showed alleviation of symptoms after two treatments and regression by seven [46]. These results support the use of laser as an adjunct therapy.

\section{RADIOFREQUENCY (RF) ABLATION}

While early experimentation with use of RF ablation on keloids saw limited benefits, recent evidence has been rather favorable [47]. Fruth et al. treated auricular keloids with RF ablation (1-7 treatments), half in combination with intralesional administration of triamcinolone, and saw improvement in $6 / 7$ treated with combination therapy and $4 / 7$ with RF ablation monotherapy [48]. A subsequent study saw improvement in 12 out of 13 lesions (92.3\%), with only one patient requiring multiple treatments; the authors acknowledged that there was no explanation for the divergence between their results and those of Fruth et al. [49] Further evaluation of combination therapy with RF ablation and steroid injection was found to decrease keloid volume (95.4\% reduction), pain, and pruritus [50]. Support of these results was found in a comparison of triamcinolone, triamcinolone and hyaluronidase, verapamil, RF, and RF with triamcinolone. Triamcinolone with hyaluronidase and RF with triamcinolone were found to have the highest clearance rates (75\%), although RF ablation carried an increased rate of adverse effects such as atrophy, ulceration, and depigmentation [12]. In summary, although complications could pose an increased risk with this treatment, optimization should be sought, as this treatment has been shown to be effective.

\section{RADIATION}

Surgical excision followed by radiation has become a mainstay of keloid treatment in an effort to prevent postoperative recurrence. Early research showed that electron beam radiation may be superior to conventional kilovoltage $\mathrm{X}$-ray therapy owing to its more even tissue distribution, touting only a $16 \%$ recurrence rate 
and a patient satisfaction rate of over 83\% [51]. A large review $(n=2515)$ of post-keloidectomy radiation found the least likelihood of recurrence with electron beam or ${ }^{60} \mathrm{Co}$ radiation as compared to other radiation options [52]. Another large retrospective study of 568 patients with 834 keloids treated with electron beam radiation post excision showed a $9.59 \%$ recurrence rate, with recurrences significantly more likely in patients who were young (up to 29 years old), female, with large (greater than $5 \mathrm{~cm}$ ) keloids, or with keloids in more tense locations. Additionally, relapses were less likely with a shorter interval from surgery to radiation, with radiation within $24 \mathrm{~h}$ being the least recurrent [53]. In a survey of patients with auricular keloids who were treated with conventional kilovoltage radiation, satisfaction with treatment was high $(4.7 / 5)$, although the number of responses was low $(n=5)$ [54].

Brachytherapy is a newer radiation option that has limited but positive results; recent work found a $6 \%$ recurrence rate after perioperative high-dose brachytherapy was used in patients who had failed previous treatments. Symptoms were also completely eliminated from all previously symptomatic patients [55]. Lastly, superficial photon radiotherapy has become popular, potentially owing to the development of new in-office machines. A study of 21 keloids using in-office postoperative radiation therapy achieved a $0 \%$ recurrence rate. Although the study size was limited and there may have been a degree of confounding due to the adjunct use of platelet-rich plasma and a proprietary topical cream, the results are nonetheless promising [56]. Recent work comparing electron beam radiation to low-energy photon radiotherapy found significantly fewer recurrences in the low-energy photon radiotherapy group, which supports previously discussed work [57]. In summary, years of data largely support radiation as an integral component in prevention of postoperative keloid recurrence. However, a study comparing excision and electron beam radiation to excision and 5-fluorouracil/triamcinolone injections found that the injections were more efficacious in reducing recurrences than radiation $(73.33 \%$ versus $42.33 \%$ efficacy, respectively) [58]. As radiation is not without risks, from pigmentary changes to purported malignancy potential, additional data is needed to confirm which patients could be best candidates for this treatment $[56,58]$.

\section{OTHER}

\section{Extracorporeal Shockwave Therapy}

Use of shockwave therapy for scar improvement is a fairly new phenomenon. A study of extracorporeal shockwave therapy on hypertrophic scars recently showed that it improved parameters such as wrinkles after 3 weeks of treatment (three sessions) [59]. A comparison of extracorporeal shockwave therapy to intralesional steroid showed no significant difference in improvement of keloids between these groups, as determined by both Patient and Observer Scar Assessment Scale (POSAS) and clinical features [60]. Such limited study prevents drawing a strong conclusion about this therapy.

\section{Pentoxifylline}

Pentoxifylline, a methyl xanthine derivative, has shown variable uses in keloid therapy. Early work showed that pentoxifylline decreased fibrosis broadly, including fibrosis resulting from radiation, and use in keloids showed potential to decrease the recurrence rate by repressing wound contraction [52, 61]. Wong et al. showed that additional benefits of pentoxifylline include halting the progression of keloids, as well as the reduction of bothersome symptoms such as pruritus and pain [62]. This symptomatic benefit could be especially useful to provide relief in patients whose keloids are large, numerous, or otherwise suboptimal for surgical consideration. In a retrospective study evaluating the addition of 6 months of postoperative pentoxifylline $(400 \mathrm{mg}$, TID) to the standard of care (intralesional triamcinolone injections), recurrence of lesions was found to be significantly decreased in high-risk patients who received the adjunct therapy versus those that did not (10.5\% versus $66.6 \%$, respectively) [63]. With postsurgical recurrence of keloids 
being one of the most serious and difficult treatment complications, current data supporting this treatment is encouraging.

\section{Dupilumab}

A single case report of an African American patient with atopic dermatitis and two concomitant popliteal fossa keloids cited dupilumab (anti-IL-4, anti-IL-13) as causing substantial keloid regression (without complete clearance). In studying skin samples from three patients with keloids but without atopic dermatitis, the authors found increased $I L-4 R$ expression in keloids, and increased $I L-13$ and CCL18 expression in both keloids and non-lesional skin (as compared to race-matched controls with neither a history of keloids nor atopic dermatitis) [64]. However, as this result has only been shown in one patient who had a concomitant inflammatory skin condition, more data is needed to show efficacy in patients with keloids.

\section{COMBINATION THERAPIES}

Because no one treatment has proven to be wholly efficacious and because treatment of keloids is dependent on a variety of factors such as location, Fitzpatrick skin type, and history of recurrence, many studies have been performed that combine established treatments to ideally generate an additive or synergistic response. For example, excision is a mainstay of therapy that has been combined with other modalities to improve recurrence rates. A study evaluating excision with $\mathrm{CO}_{2}$ laser additionally used compression, silicone sheets, and cyanoacrylate glue to improve results [65]. Likewise, triamcinolone injections are often added to other treatments owing to their known efficacy. Combination therapy including two types of laser (nonablative fractional erbium-glass and ablative fractional $\mathrm{CO}_{2}$ ), superficial cryotherapy (using a handheld device, three freeze-thaw cycles), and triamcinolone injection was found to produce a large improvement in a relatively short amount of time as compared to previous literature of the monotherapies [66]. Another study showed that combination therapy including RF ablation and electron beam radiation reduced VSS scores (all characterized as "good" or "fair") while largely improving patient satisfaction $(73.3 \%$ reported extremely satisfied). The authors proposed that this treatment combination could be especially useful in patients with large or multiple keloids that are not appropriate for surgery [67].

\section{COMPARISONS}

As a result of the breadth of keloid treatment options, some work has been done to directly compare various therapies. Behera et al. compared results of keloid destruction with cryotherapy (using a cryoprobe; two freeze-thaw cycles) vs $\mathrm{CO}_{2}$ laser, both followed by steroid injections. While some initial differences were seen between the groups, differences in parameters such as recurrence and VSS score were not statistically significant at 12 months. While pain reduction was significantly higher in the $\mathrm{CO}_{2}$ laser group, the authors largely found that these two treatments are equivalent [68]. Sabry et al. found that the combination of $\mathrm{CO}_{2}$ laser with either topical verapamil or 5-fluorouracil was more efficacious than laser alone, with no adverse effects [69]. A randomized controlled trial evaluating intralesional cryotherapy as compared to excision and steroid or excision and brachytherapy performed by Bijlard et al. was stopped because of significantly inferior results in the intralesional cryotherapy group. Specifically, they note that brachytherapy is more efficacious for keloids that historically were unresponsive to intralesional corticosteroid therapy or recurrent after surgery. While an improvement was seen with cryotherapy in keloids that were not treatmentresistant, corticosteroids nevertheless seemed to give a more robust improvement [70].

\section{CONCLUSION}

There have never been more options for keloid treatment than what is available currently. However, because the majority have either seen conflicting results or have not progressed to 
optimization, it is difficult to compare results across the board to suggest what may be the most advantageous treatment option. Additionally, as patient characteristics such as age, Fitzpatrick skin type, gender, keloid location or size, keloid number, history of recurrence, and personal interest in various therapies can play an important role, the increased number of efficacious options allows for an ever more dynamic interaction between patients and their healthcare providers about their disease and treatment options.

\section{ACKNOWLEDGEMENTS}

Funding. No funding or sponsorship was received for this study or publication of this article.

Authorship. All named authors meet the International Committee of Medical Journal Editors (ICMJE) criteria for authorship for this article, take responsibility for the integrity of the work as a whole, and have given their approval for this version to be published.

Disclosures. Emily E. Limmer and Donald A. Glass, II have nothing to disclose.

Compliance with Ethics Guidelines. This article is based on previously conducted studies and does not contain any studies with human participants or animals performed by any of the authors.

Open Access. This article is licensed under a Creative Commons Attribution-NonCommercial 4.0 International License, which permits any non-commercial use, sharing, adaptation, distribution and reproduction in any medium or format, as long as you give appropriate credit to the original author(s) and the source, provide a link to the Creative Commons licence, and indicate if changes were made. The images or other third party material in this article are included in the article's Creative Commons licence, unless indicated otherwise in a credit line to the material. If material is not included in the article's Creative Commons licence and your intended use is not permitted by statutory regulation or exceeds the permitted use, you will need to obtain permission directly from the copyright holder. To view a copy of this licence, visit http:// creativecommons.org/licenses/by-nc/4.0/.

\section{REFERENCES}

1. Viera $\mathrm{MH}$, Caperton $\mathrm{CV}$, Berman B. Advances in the treatment of keloids. J Drugs Dermatol. 2011;10(5): 468-80.

2. Olaitan PB. Keloids: assessment of effects and psychosocial-impacts on subjects in a black African population. Indian J Dermatol Venereol Leprol. 2009;75(4):368-72.

3. Goutos I, Ogawa R. Steroid tape: a promising adjunct to scar management. Scars Burn Heal. 2017;3:2059513117690937.

4. Hendricks T, Martens MF, Huyben CM, Wobbes T. Inhibition of basal and TGF beta-induced fibroblast collagen synthesis by antineoplastic agents. Implications for wound healing. Br J Cancer. 1993;67(3): 545-50.

5. Espana A, Solano T, Quintanilla E. Bleomycin in the treatment of keloids and hypertrophic scars by multiple needle punctures. Dermatol Surg. 2001;27(1):23-7.

6. Bodokh I, Brun P. Treatment of keloid with intralesional bleomycin. Ann Dermatol Venereol. 1996;123(12):791-4.

7. Camacho-Martinez FM, Rey ER, Serrano FC, Wagner A. Results of a combination of bleomycin and triamcinolone acetonide in the treatment of keloids and hypertrophic scars. An Bras Dermatol. 2013;88(3):387-94.

8. Payapvipapong $\mathrm{K}$, Niumpradit $\mathrm{N}$, Piriyanand $\mathrm{C}$, Buranaphalin S, Nakakes A. The treatment of keloids and hypertrophic scars with intralesional bleomycin in skin of color. J Cosmet Dermatol. 2015;14(1):83-90.

9. Manca G, Pandolfi P, Gregorelli C, Cadossi M, de Terlizzi F. Treatment of keloids and hypertrophic scars with bleomycin and electroporation. Plast Reconstr Surg. 2013;132(4):621e-e630630.

10. Danielsen PL, Rea SM, Wood FM, et al. Verapamil is less effective than triamcinolone for prevention of 
keloid scar recurrence after excision in a randomized controlled trial. Acta Derm Venereol. 2016;96(6):774-8.

11. El-Kamel MF, Selim MK, Alghobary MF. Keloidectomy with core fillet flap and intralesional verapamil injection for recurrent earlobe keloids. Indian J Dermatol Venereol Leprol. 2016;82(6):659-65.

12. Aggarwal A, Ravikumar BC, Vinay KN, Raghukumar S, Yashovardhana DP. A comparative study of various modalities in the treatment of keloids. Int J Dermatol. 2018;57(10):1192-200.

13. Abedini R, Sasani $P$, Mahmoudi HR, Nasimi M, Teymourpour A, Shadlou Z. Comparison of intralesional verapamil versus intralesional corticosteroids in treatment of keloids and hypertrophic scars: a randomized controlled trial. Burns. 2018;44(6):1482-8.

14. Ahuja RB, Chatterjee P. Comparative efficacy of intralesional verapamil hydrochloride and triamcinolone acetonide in hypertrophic scars and keloids. Burns. 2014;40(4):583-8.

15. Margaret Shanthi FX, Ernest K, Dhanraj P. Comparison of intralesional verapamil with intralesional triamcinolone in the treatment of hypertrophic scars and keloids. Indian J Dermatol Venereol Leprol. 2008;74(4):343-8.

16. D'Andrea F, Brongo S, Ferraro G, Baroni A. Prevention and treatment of keloids with intralesional verapamil. Dermatology. 2002;204(1):60-2.

17. Salwowska NM, Bebenek KA, Żąłło DA, WcisłoDziadecka DL. Physiochemical properties and application of hyaluronic acid: a systematic review. J Cosmet Dermatol. 2016;15(4):520-6.

18. Di Stadio A. Ear keloid treated with infiltrated noncross-linked hyaluronic acid and cortisone therapy. In Vivo. 2016;30(5):695-9.

19. Nakamura H, Gotoh M, Kanazawa T, et al. Effects of corticosteroids and hyaluronic acid on torn rotator cuff tendons in vitro and in rats. J Orthop Res. 2015;33(10):1523-30.

20. Zhibo X, Miaobo Z. Intralesional botulinum toxin type A injection as a new treatment measure for keloids. Plast Reconstr Surg. 2009;124(5): 275e-e277277.

21. Gauglitz GG, Bureik D, Dombrowski Y, Pavicic T, Ruzicka T, Schauber J. Botulinum toxin A for the treatment of keloids. Skin Pharmacol Physiol. 2012;25(6):313-8.

22. Robinson AJ, Khadim MF, Khan K. Keloid scars and treatment with botulinum toxin type A: the Belfast experience. J Plast Reconstr Aesthet Surg. 2013;66(3):439-40.

23. Shaarawy E, Hegazy RA, Abdel Hay RM. Intralesional botulinum toxin type A equally effective and better tolerated than intralesional steroid in the treatment of keloids: a randomized controlled trial. J Cosmet Dermatol. 2015;14(2):161-6.

24. Rasaii S, Sohrabian N, Gianfaldoni S, et al. Intralesional triamcinolone alone or in combination with botulinium toxin $\mathrm{A}$ is ineffective for the treatment of formed keloid scar: a double blind controlled pilot study. Dermatol Ther. 2019;32(2):e12781.

25. Pruksapong C, Yingtaweesittikul S, Burusapat C. Efficacy of botulinum toxin A in preventing recurrence keloids: double blinded randomized controlled trial study: intraindividual subject. J Med Assoc Thailand. 2017;100(3):280-6.

26. Bi M, Sun P, Li D, Dong Z, Chen Z. Intralesional injection of botulinum toxin type A compared with intralesional injection of corticosteroid for the treatment of hypertrophic scar and keloid: a systematic review and meta-analysis. Med Sci Monit. 2019;25:2950-8.

27. Fanous A, Bezdjian A, Caglar D, et al. Treatment of keloid scars with botulinum toxin type A versus triamcinolone in an athymic nude mouse model. Plast Reconstr Surg. 2019;143(3):760-7.

28. Kang N, Sivakumar B, Sanders R, Nduka C, Gault D. Intra-lesional injections of collagenase are ineffective in the treatment of keloid and hypertrophic scars. J Plast Reconstr Aesthet Surg. 2006;59(7): 693-9.

29. Bae-Harboe Y-SC, Harboe-Schmidt JE, Graber E, Gilchrest BA. Collagenase followed by compression for the treatment of earlobe keloids. Dermatol Surg. 2014;40(5):519-24.

30. Mourad B, Elfar N, Elsheikh S. Spray versus intralesional cryotherapy for keloids. J Dermatolog Treat. 2016;27(3):264-9.

31. Litrowski N, Boullie MC, Dehesdin D, De Barros A, Joly P. Treatment of earlobe keloids by surgical excision and cryosurgery. J Eur Acad Dermatol Venereol. 2014;28(10):1324-31.

32. van Leeuwen MCE, van der Wal MBA, Bulstra A-EJ, et al. Intralesional cryotherapy for treatment of keloid scars: a prospective study. Plast Reconstr Surg. 2015;135(2):580-9.

33. Park TH, Cho H-J, Lee JW, et al. Could $-79{ }^{\circ} \mathrm{C}$ spray-type cryotherapy be an effective monotherapy for the treatment of keloid? Int J Mol Sci. 2017;18(12):2536. 
34. Azzam EZ, Omar SS. Treatment of auricular keloids by triple combination therapy: surgical excision, platelet-rich plasma, and cryosurgery. J Cosmet Dermatol. 2018;17(3):502-10.

35. Wang X, Wu X, Liu K, et al. Topical cryoanesthesia for the relief of pain caused by steroid injections used to treat hypertrophic scars and keloids. Medicine. 2017;96(43):e8353.

36. Srinivas CR, Kumaresan M. Lasers for vascular lesions: standard guidelines of care. Indian J Dermatol Venereol Leprol. 2011;77(3):349-68.

37. Shih P-Y, Chen H-H, Chen C-H, Hong H-S, Yang $\mathrm{C}-\mathrm{H}$. Rapid recurrence of keloid after pulse dye laser treatment. Dermatol Surg. 2008;34(8):1124-7.

38. Eke U, Diaz C, Abdullah A. Keloid scars in type VI skin successfully treated with combined surgery and pulsed dye laser therapy. $\mathrm{Br} \mathrm{J}$ Dermatol. 2013;168(6):1360-2.

39. Yang Q, Ma Y, Zhu R, et al. The effect of flashlamp pulsed dye laser on the expression of connective tissue growth factor in keloids. Lasers Surg Med. 2012;44(5):377-83.

40. Cannarozzo G, Sannino M, Tamburi F, Morini C, Nistico SP. Flash-lamp pulsed-dye laser treatment of keloids: results of an observational study. Photomed Laser Surg. 2015;33(5):274-7.

41. Zhibo X, Miaobo Z. Molecular mechanism of pulsed-dye laser in treatment of keloids: an in vitro study. Adv Skin Wound Care. 2010;23(1):29-33.

42. Azzam OA, Bassiouny DA, El-Hawary MS, El Maadawi ZM, Sobhi RM, El-Mesidy MS. Treatment of hypertrophic scars and keloids by fractional carbon dioxide laser: a clinical, histological, and immunohistochemical study. Lasers Med Sci. 2016;31(1): 9-18.

43. Kraeva E, Ho D, Jagdeo J. Successful treatment of keloid with fractionated carbon dioxide $\left(\mathrm{CO}_{2}\right)$ laser and laser-assisted drug delivery of triamcinolone acetonide ointment in an African-American man. J Drugs Dermatol. 2017;16(9):925-7.

44. Rossi A, Lu R, Frey MK, Kubota T, Smith LA, Perez $\mathrm{M}$. The use of the $300 \mathrm{microsecond} 1064 \mathrm{~nm} \mathrm{Nd}$ : YAG laser in the treatment of keloids. J Drugs Dermatol. 2013;12(11):1256-62.

45. Al-Mohamady AE-SAE-H, Ibrahim SMA, Muhammad MM. Pulsed dye laser versus long-pulsed Nd: YAG laser in the treatment of hypertrophic scars and keloid: a comparative randomized split-scar trial. J Cosmet Laser Ther. 2016;18(4):208-12.
46. Martin MS, Collawn SS. Combination treatment of $\mathrm{CO}_{2}$ fractional laser, pulsed dye laser, and triamcinolone acetonide injection for refractory keloid scars on the upper back. J Cosmet Laser Ther. 2013;15(3):166-70.

47. Meshkinpour A, Ghasri P, Pope K, et al. Treatment of hypertrophic scars and keloids with a radiofrequency device: a study of collagen effects. Lasers Surg Med. 2005;37(5):343-9.

48. Fruth K, Gouveris H, Kuelkens C, Mann WJ. Radiofrequency tissue volume reduction for treatment of auricle keloids. Laryngoscope. 2011;121(6): 1233-6.

49. Klockars T, Back LJ, Sinkkonen ST. Radiofrequency ablation for treatment of auricular keloids: our experience in eleven patients. Clin Otolaryngol. 2013;38(5):381-5.

50. Weshay AH, Abdel Hay RM, Sayed K, El Hawary MS, Nour-Edin F. Combination of radiofrequency and intralesional steroids in the treatment of keloids: a pilot study. Dermatol Surg. 2015;41(6):731-5.

51. Maarouf M, Schleicher U, Schmachtenberg A, Ammon J. Radiotherapy in the management of keloids. Clinical experience with electron beam irradiation and comparison with X-ray therapy. Strahlenther Onkol. 2002;178(6):330-5.

52. Flickinger JC. A radiobiological analysis of multicenter data for postoperative keloid radiotherapy. Int J Radiat Oncol Biol Phys. 2011;79(4):1164-70.

53. Shen J, Lian X, Sun Y, et al. Hypofractionated electron-beam radiation therapy for keloids: retrospective study of 568 cases with 834 lesions. J Radiat Res. 2015;56(5):811-7.

54. Eaton DJ, Barber E, Ferguson L, Mark Simpson G, Collis CH. Radiotherapy treatment of keloid scars with a kilovoltage X-ray parallel pair. Radiother Oncol. 2012;102(3):421-3.

55. Jiang P, Baumann R, Dunst J, et al. Perioperative interstitial high-dose-rate brachytherapy for the treatment of recurrent keloids: feasibility and early results. Int J Radiat Oncol Biol Phys. 2016;94(3): 532-6.

56. Jones ME, Hardy C, Ridgway J. Keloid management: a retrospective case review on a new approach using surgical excision, platelet-rich plasma, and in-office superficial photon $\mathrm{x}$-ray radiation therapy. Adv Skin Wound Care. 2016;29(7):303-7.

57. Yang X, Shao Y, Yu W, et al. A novel radiotherapy approach for keloids with intrabeam. Biomed Res Int. 2019;2019:4693528. 
58. Khalid FA, Farooq UK, Saleem M, et al. The efficacy of excision followed by intralesional 5-fluorouracil and triamcinolone acetonide versus excision followed by radiotherapy in the treatment of ear keloids: a randomized control trial. Burns. 2018;44(6):1489-95.

59. Zhao J-C, Zhang B-R, Shi K, Wang J, Yu Q-H, Yu J-A. Lower energy radial shock wave therapy improves characteristics of hypertrophic scar in a rabbit ear model. Exp Ther Med. 2018;15(1):933-9.

60. Wang C-J, Ko J-Y, Chou W-Y, Cheng J-H, Kuo Y-R. Extracorporeal shockwave therapy for treatment of keloid scars. Wound Repair Regen. 2018;26(1): 69-766.

61. Dans MJ, Isseroff R. Inhibition of collagen lattice contraction by pentoxifylline and interferon-alpha, -beta and -gamma. J Invest Dermatol. 1994;102(1): 118-21.

62. Wong TW, Lee JY, Sheu HM, Chao SC. Relief of pain and itch associated with keloids on treatment with oxpentifylline. Br J Dermatol. 1999;140(4):771-2.

63. Tan A, Martinez Luna O, Glass DA, 2nd. Pentoxifylline for the prevention of postsurgical keloid recurrence. Dermatol Surg. 2019. https://doi.org/ 10.1097/DSS.0000000000002090.

64. Diaz A, Tan $\mathrm{K}, \mathrm{He} \mathrm{H}$, et al. Keloid lesions show increased IL-4/IL-13 signaling and respond to Th2targeting dupilumab therapy. J Eur Acad Dermatol Venereol. 2020;34(4):e161-4.
65. Tenna S, Aveta A, Filoni A, Persichetti P. A new carbon dioxide laser combined with cyanoacrylate glue to treat earlobe keloids. Plast Reconstr Surg. 2012;129(5):843e.

66. Lee YI, Kim J, Yang CE, Hong JW, Lee WJ, Lee JH. Combined therapeutic strategies for keloid treatment. Dermatol Surg. 2019;45(6):802-10.

67. Zhang W, Liu Z, Zhu L, et al. Combining microplasma radio-frequency with hypofractionated electron-beam radiation as a novel treatment of keloids: a case series. Medicine. 2019;98(48): e18094.

68. Behera B, Kumari R, Thappa DM, Malathi M. Therapeutic efficacy of intralesional steroid with carbon dioxide laser versus with cryotherapy in treatment of keloids: a randomized controlled trial. Dermatol Surg. 2016;42(10):1188-98.

69. Sabry HH, Abdel Rahman SH, Hussein MS, Sanad RR, Abd El Azez TA. The efficacy of combining fractional carbon dioxide laser with verapamil hydrochloride or 5-fluorouracil in the treatment of hypertrophic scars and keloids: a clinical and immunohistochemical study. Dermatol Surg. 2019;45(4):536-46.

70. Bijlard E, Timman R, Verduijn GM, Niessen FB, Hovius SER, Mureau MAM. Intralesional cryotherapy versus excision with corticosteroid injections or brachytherapy for keloid treatment: randomised controlled trials. J Plast Reconstr Aesthet Surg. 2018;71(6):847-56. 